\title{
Saudi EFL students' preferences for correction of classroom oral errors: Are teachers aware?
}

\author{
Alharbi, Hanadi $\bowtie$ \\ Qassim University, Saudi Arabia (hanadi244@gmail.com)
}

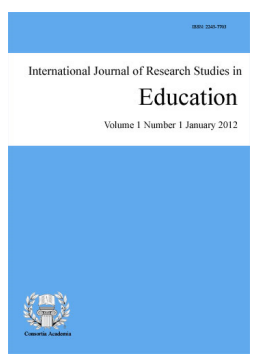

Accepted: 30 August 2020

ISSN: $2243-7703$ Online ISSN: 2243-7711

OPEN ACCESS

\section{Abstract}

Students' preferences for oral error correction can be one of the crucial elements that influence their success in language learning. If teachers try to identify and match these preferences, this can increase the students' eagerness to learn the target language. As error correction is one of the essential practices in language classrooms, students need to be given a chance to express their preferences about how they prefer to be corrected, and teachers need to acquaint themselves with students' preferences. The aim of this study was to determine male and female Saudi EFL students' preferences for the correction of oral errors and to find out the similarities and differences between their preferences. Concurrently, the extent of teachers' awareness of Saudi EFL students' preferences for the correction of oral errors was also investigated for the first time. One hundred Saudi EFL students (50 males and 50 females) enrolled in an intensive English course at Qassim University, Saudi Arabia, were randomly selected to participate in this study. Furthermore, eight teachers were included in this study. The data was collected through the administration of two questionnaires. The results revealed that the preferences of the male and female students were very similar. The teachers were aware of most of the students' preferences but they were unaware of some of their preferences. The study clarified that the students preferred to be corrected in a certain way. For example, they did not want their teachers to correct their errors in private sessions.

Keywords: timing; privacy; self-correction; peer correction, techniques 


\section{Saudi EFL students' preferences for correction of classroom oral errors: Are teachers aware?}

\section{Introduction}

English is the dominant mode of communication worldwide (Alrashidi \& Phan, 2015). It is taught as a subject in basic education and many higher education institutions throughout the world. The students who master English language skills tend to have better occupational opportunities than those who do not. This has encouraged people all over the world to learn English. Techers' reactions to students' errors can affect the process of language learning (Alhaysony, 2016). The corrections made by teachers can aid students in gaining a better understanding of how the target language works (Calsiyao, 2015). Teachers need to correct students' errors in a way that does not discourage them (Qasaimeh \& Gasaymeh, 2016). Considering the students' feelings is increasingly essential when correcting their oral errors because students are usually corrected in front of the whole class (Genç, 2014). Teachers' decisions about how to provide appropriate error correction should take into account the students' needs and preferences (Firwana, 2010). For this reason, teachers need to familiarize themselves with students' preferences for instructional practices (Fidan, 2015). The appropriateness of error correction mainly depends on whether the provided correction matches the students' preferences (Farahani \& Salajegheh, 2015). Therefore, students need to be provided with a central role in making decisions about their learning process. Furthermore, teachers need to be aware of students' preferences regarding how they desire to learn.

An increasing number of studies have focused on students' preferences for correction of oral errors (Abedi et al., 2015; Azar \& Molavi, 2013; Genç, 2014; Khorshidi \& Rassaei, 2013; Papangkorn, 2015; Yousefi, 2016). However, only a few studies have been conducted on Arab EFL students in general and Saudi EFL students in particular. In Saudi Arabia, only a few studies (Alamri \& Fawzi, 2016; Alhaysony, 2016; Almuhimedi \& Alshumaimeri, 2015) have attempted to explore Saudi EFL students' preferences for oral error correction. Among these studies, only one study (Alhaysony, 2016) included male and female students and compared their preferences. Moreover, all the studies that have investigated EFL students' preferences for oral error correction did not attempt to determine to what extent teachers were aware of the students' preferences. Measuring the extent of the teachers' awareness of the students' preferences can help in identifying what the teachers know and do not know about the students' preferences. Then, different means such as training programs can be used to increase the teachers' knowledge of the students' preferences. The teachers who have sufficient awareness of the students' preferences can efficiently adjust their teaching to accommodate the students' preferences. Consequently, there is a need for additional studies that describe the current state of Saudi EFL students' preferences regarding different aspects of oral error correction. The current state of teachers' awareness of Saudi EFL students' preferences for oral error correction also needs to be explored.

\subsection{Research problem}

In Saudi Arabia, one of the challenges that students face while learning English is that they lack the social target environment in which they can practice (Alrashidi \& Phan, 2015). Arabic is the official language in Saudi Arabia, whereas English is taught as a foreign language. Consequently, English in Saudi Arabia is not actively used in everyday communication (Alrabai, 2014) because most Saudis communicate in their mother tongue (Alrashidi \& Phan, 2015). Accordingly, the classroom is a central place for Saudi EFL students to learn English because it offers them the opportunity to practice English. Therefore, teachers need to create a comfortable classroom atmosphere that encourages students to practice English.

In general, teachers are concerned about how to improve their students' achievements. However, teachers might not be aware that some of their instructional practices in the classroom might negatively affect their

88 Consortia Academia Publishing (A partner of Network of Professional Researchers and Educators) 
students' feelings and, consequently, their learning. For example, in Al-Saraj's (2014) study of Saudi EFL university students' experience of foreign language anxiety, the participants revealed that they felt anxious when teachers interrupted them to correct their errors. The participants also reported that they avoided doing live presentations; instead, they recorded their presentations and then played the recording in the classroom. The students disclosed that they gave oral presentations in this way because they wanted to avoid making errors and, consequently, avoid being corrected in front of their classmates. Furthermore, Hamouda (2013) conducted a study on Saudi EFL university students and found that teachers' correction was one of the main reasons that students were reluctant to speak in the classroom.

Moreover, based on my experience in teaching English to Saudi EFL university students, students remain silent in the classroom if they are not sure that what they want to say is linguistically correct. After a number of discussions with the students, I discovered that the students had bad prior experiences with teachers' corrections of their oral errors. For instance, some teachers completely ignored the students' oral errors, whereas other teachers corrected oral errors using a harsh tone of voice, particularly if the students failed to self-correct the errors related to something that they had already studied.

Considering the aspects mentioned above, it is evident that Saudi EFL university students generally do not feel comfortable with teachers' correction of oral errors. As a result, the students resort to avoidance behaviors such as avoiding live presentations and remaining silent in the classroom. These avoidance behaviors can have negative effects on the students' speaking proficiency. Therefore, teachers need to have a clear insight into students' preferences for different aspects of oral error correction. As such, it is important to investigate Saudi EFL university students' preferences for the correction of oral errors and to examine the degree of teachers' awareness of these preferences.

\subsection{Research questions}

The present study sought to answer the following questions:

1. What are male and female Saudi EFL university students' preferences for oral error correction?

2. What are the similarities and differences between male and female Saudi EFL university students in terms of their preferences for oral error correction?

3. To what extent are teachers aware of Saudi EFL university students' preferences for oral error correction?

\section{Related studies}

Saudi EFL students' perception of oral error correction has not been investigated prior to 2015. In 2015 and 2016, three studies (Alamri \& Fawzi, 2016; Alhaysony, 2016; Almuhimedi \& Alshumaimeri, 2015) focused on exploring Saudi EFL students' perspective on oral error correction. Almuhimedi and Alshumaimeri (2015) investigated Saudi EFL students' perspectives of the correction of grammatical errors. The participants were female secondary school students. They were offered a questionnaire that asked them to indicate their preferences for grammatical error correction. The results of the questionnaire demonstrated that the students wanted to receive correction for their grammatical errors. However, they did not want the teachers to correct every grammatical error. The results also revealed that the students preferred to receive the correction after the end of the class. Many students in the study did not prefer teachers to correct them individually; they wanted to receive the correction during group activities.

Alamri and Fawzi (2016) performed a study to identify the preferences of Saudi EFL students for oral error correction. The study investigated the preferences of female university students by using a questionnaire. The questionnaire findings revealed that the students wished to receive oral error correction. Unlike the secondary school students in the previous study, the university students in this study preferred immediate correction to 
delayed correction. The students preferred the oral correction technique in which teachers repeat what students have said and replace the error with the correct response and the technique in which teachers point out the error and provide the correct response. Moreover, the students did not prefer the technique in which teachers directly asked students to say the correct response and the technique of ignoring students' errors.

In Saudi Arabia, the perception of male and female Saudi EFL students and the comparison between the preferences of the two genders has only been performed in one study (Alhaysony, 2016). Alhaysony (2016) conducted a study to establish the effect of several variables (gender, students' proficiency level, and students' major) on Saudi EFL students' attitudes towards oral error correction. The male and female students desired to receive oral error correction. As for the frequency and the amount of correction, male and female students wanted all their oral errors to be always corrected. Additionally, both the male and female students preferred to be corrected after they finish speaking. Alhaysony also found that the students preferred the technique in which teachers ask students to repeat their utterances. However, both the male and female students did not prefer the technique in which teachers ignore students' errors. Alhaysony indicated that there were a significant gender differences between the male and female students' perception of error correction. The female students showed more positive attitudes than the male students towards oral error correction.

It is clear that only a small number of studies have been conducted on the preferences of Saudi EFL students. In addition, most of these studies did not investigate the similarities and differences between the preferences of the male and female students. Alhaysony's study (2016) is the only study that paid attention to the similarities and differences between the preferences of the male and female students. Therefore, there is still room for more research in this area to gather more information from different resources.

This study expanded the investigation in some of the themes; most of the studies that have investigated the preferences of the Saudi EFL students asked them about their preferences for the correction of serious errors, less serious errors, frequent errors, infrequent errors and individual errors. The questionnaire of the current study focused on more specific types of errors and elicited the students' preferences for the correction of grammatical errors, phonological errors, vocabulary errors, errors of inappropriate expressions and discourse organization errors. Including these types of errors can provide a detailed description concerning the Saudi EFL students' preferences for the types of errors that they would like to be corrected. This kind of description can add valuable knowledge not only to our understanding of the students' preferences but also to our understanding of the areas of the English language that the Saudi EFL students find most problematic, and whether they prefer their teachers to help them by providing the correction. Moreover, the extent of privacy that the Saudi EFL students would like to have while receiving the correction has never been included in previous research. The current study was interested in finding more information about this area to help teachers to provide the correction to the students in a convenient way.

Besides the scarcity of research studies that aimed to find the similarities and differences between the preferences of male and female students for oral error correction, none of the previous studies were extended to examine the teachers' awareness of the students' preferences. Teachers' awareness of the students' preferences can aid them in creating a pleasant learning experience for the students. Therefore, the results of this study that describe the teachers' awareness of the students' preferences for oral error correction can lead to a number of useful conclusions that can be utilized to improve the current situation of the teachers' awareness of the students' preferences.

\section{Methodology}

\subsection{Type of study}

This study was elaborated in a quantitative descriptive frame. Brown (2011) provided a straightforward definition of quantitative research. In his words, "Quantitative research can be defined as any research that

90 Consortia Academia Publishing (A partner of Network of Professional Researchers and Educators) 
focuses on counting things and on understanding the patterns that emerge from those counts" (Brown, 2011, p. 192). According to Dörnyei (2007), quantitative methods help to conduct systematic and highly controlled investigation that help researchers to obtain reliable findings that are independent from researchers' subjectivity. Therefore, this study collected quantified information about students' preferences for oral error correction and teachers' awareness of these preferences, and the results of this study were also presented in percentages. On the other hand, descriptive studies provide the basis for understanding a phenomenon (Jackson, 2012). Accordingly, conducting this descriptive study can result in a detailed description of the Saudi EFL students' preferences for oral error correction and teachers' awareness of these preferences. This description can enhance our understanding of the topic. Therefore, the quantitative descriptive design fits the research purpose of the current study.

\subsection{Sample of the study}

Students - This study was conducted on Saudi EFL students enrolled in an intensive English course at Qassim University, Saudi Arabia. To join the Department of English Language and Translation at Qassim University, the students need to fulfill one of two conditions. The first condition is to score 4.5 in the Academic IELTS exam or 50 on TOEFL IBT. The students who do not succeed in attaining these scores need to meet the second condition, that is, to pass the English intensive course by achieving a GPA that is not less than $60 \%$. The duration of this course is one semester (four months). The main goal of the course is to train the students in the basic skills of English: reading, writing, listening, and speaking. In addition to this, students study a subject that aims to build their vocabulary. Therefore, the intensive course prepares the students to study in the Department of English Language and Translation. The educational system in Saudi Arabia separates male and female students in all years of education. However, the current study was interested in ascertaining whether male and female Saudi EFL students differ in terms of their preferences for oral error correction. Therefore, the sample of the present study was randomly selected, and it consisted of 50 male students in the Faculty of Arabic Language and Social Studies in Buraidah and 50 female students in the Faculty of Science and Arts in Buraidah. Therefore, the total number of participants was 100. All the students were native speakers of Arabic.

Teachers - The teachers who taught the students that participated in this study were included in this study to gain an understanding of the extent to which the teachers were aware of the Saudi EFL students' preferences for oral error correction. There were eight teachers in this study: four males and four females. As stated earlier, male and female students in Saudi Arabia study in separate places. Consequently, the male teachers in this study only taught the male students, whereas the female teachers in this study only taught the female students.

\subsection{Instrument}

A questionnaire was used to easily and efficiently collect the data from the male and female students and teachers. The questionnaire items were extracted from instruments used in previous studies to determine students' preferences for oral error correction (Al-Faki \& Siddiek, 2013; Firwana, 2010; Fukuda, 2004; Katayama, 2007; Smith, 2010). Some of the items were modified to make the questionnaire relevant and appropriate for the participants in this study. There were two versions of the questionnaire used in this study. The first version was distributed to the male and female students, whereas the second version was distributed to the teachers. The student version of the questionnaire consisted of two parts. The first part was designed to collect demographic information about the students, whereas the second part was provided to find out the students' preferences for oral error correction. The total number of statements in the student questionnaire was 27 . To avoid any misunderstanding, the researcher translated the questionnaire into Arabic.

On the other hand, the aim of the teacher version of the questionnaire was to determine to what extent the teachers were aware of the students' preferences for oral error correction. Therefore, the teacher version did not ask the teachers about their preferences. Instead, it asked them what they know about the students' preferences. The teacher version of the questionnaire was also divided in two parts. The first part was constructed to elicit the 
Alharbi, $\mathrm{H}$.

teachers' demographic information, whereas the second part was made to measure the teachers' awareness. There were also 27 statements in this questionnaire. In the two versions of the questionnaire, the responses were given on a 4-point Likert scale (strongly agree, agree, disagree and strongly disagree). However, for analyzing the questionnaire, the data were simplified by limiting the 4-point scale to a 2-point scale (agree and disagree).

Validity of the questionnaire - The validity of an instrument is the instrument's ability to measure what it is supposed to measure (Dörnyei, 2007). Before using the questionnaire to collect data, it was offered to four university professors in the Department of English Language and Translation at Qassim University. These professors are experts in teaching English as a foreign language. The professors were provided with the necessary details to make them understand the purpose of this study. Furthermore, these professors were requested to judge the questionnaire statements according to a number of criteria. The professors' comments and suggestions were taken into account before producing the final versions of the questionnaire. As stated earlier, the student version of the questionnaire was translated into Arabic to avoid any misunderstanding. The researcher is a native speaker of Arabic. Moreover, the Arabic version of the questionnaire was offered to a professor of English at Qasim University, whose native language is Arabic. The professor was requested to ensure that the Arabic version was equivalent to the English version in meaning and validity.

Reliability of the questionnaire - The reliability of an instrument refers to the instrument's ability to yield similar results each time it is administered to a similar group of respondents in a similar context (Cohen et al., 2000). Before using the questionnaire to collect data, a pilot study was conducted to check the reliability of the questionnaire and to ensure that the participants will not encounter any difficulties. Forty students (20 male and 20 female) were randomly selected from the target population to pilot the questionnaire. These students were excluded from the main study. As Cronbach and Shavelson (2004) explained, Cronbach's alpha measures the internal consistency that describes the extent to which all items in a test measure the same concept or construct. In this study, Cronbach's alpha was calculated to test the reliability of the questionnaire. The statistical result of the test was (0.840). This result indicates that the questionnaire was sufficiently reliable. Tavakol and Dennick (2011) established that the acceptable values of alpha range from .70 to .95 .

\subsection{Data collection}

To collect the required data to answer the research questions, the researcher visited the female teachers in their offices to explain the purpose of this study and to invite them to participate. Because of the small number of the female teachers who teach the students in the intensive English course in the Faculty of Science and Arts in Buraidah, the researcher decided to include them all. There were five female teachers, and they all agreed to participate in this study. However, one of them did not complete her questionnaire; therefore, she was excluded from this study. Furthermore, the researcher coordinated with the female teachers to arrange an appropriate date on which the researcher could visit the female students and distribute the questionnaire. Subsequently, the researcher visited the female students in the classroom and explained the purpose of the study in Arabic to ensure that they understood the aim. Additionally, the students were informed that they are free to agree or disagree to take part in the study, and they are free to ask the researcher any question regarding the study. Next, the researcher distributed the questionnaire to the female students and asked them to complete it and return it immediately. The female students took approximately 15-20 minutes to complete the questionnaire.

As mentioned, the educational system in Saudi Arabia separates male and female students. Therefore, the researcher could not visit the male teachers in their offices and the male students in their classrooms. The teacher and student versions of the questionnaire were distributed by a professor that teaches English in the same faculty and department to which the male students and teachers of this study belong. This professor volunteered to distribute the questionnaire. The professor was aware of the points that should be taken into account while administering the questionnaire. Moreover, the researcher conducted a number of phone calls with the professor to help him distribute the questionnaire to male students and teachers in the same way as with female students and teachers. Because of the small number of male teachers who teach the students in the intensive course in the

92 Consortia Academia Publishing (A partner of Network of Professional Researchers and Educators) 
Faculty of Arabic Language and Social Studies, the researcher included them all. There were four teachers, and the purpose of this study was explained to them. The four teachers agreed to participate in this study and completed their questionnaires. In addition, the purpose of this study was explained to male students in Arabic. The male students also completed the questionnaire and returned it immediately to the professor that distributed the questionnaire to them. They also spent approximately 20 minutes to complete the questionnaire.

\subsection{Data analysis}

After collecting the questionnaire from the respondents, the frequency of each response to each item of the questionnaire was counted and presented as a percentage to discover the general trend of the students' preferences for oral error correction. Furthermore, the Chi-squared test was utilized to determine the similarities and differences between the preferences of the male and female students. As for the teachers' awareness of the students' preferences, the percentile of the binary criterion was used to measure the overall score of the respondents' opinions. Here, it should be taken into account that the students and the teachers were asked to choose their answers from a 4-point Likert scale (strongly agree, agree, disagree, and strongly disagree). However, to simplify the data analysis, the 4-point scale was limited to a 2-point scale (agree and disagree).

\section{Findings and Discussion}

The first part of the questionnaire gathered demographic data from the respondents. The analysis indicated that 50 male students and 50 female students participated in this study. They were aged between 18 and 24 years old. The majority of them started studying English when they were in the sixth grade of elementary school. Four male and four female teachers participated in the current study. Their ages ranged from 30 to 60 . Seven of the teachers were Pakistani and one was Algerian. All of them were MA holders. Their teaching experience ranged between 10 and 30 years. The second part of the teacher and student questionnaires had three sections. The results of these sections are presented and discussed in light of the previous studies.

\subsection{Preferences for receiving oral error correction}

In the first section of the questionnaire, the students were asked whether they agreed with the statement, "I prefer teachers to correct errors that I make when speaking English in the classroom." An equal percentage (94\%) of both male and female students agreed with the statement. Accordingly, male and female students exhibited a high degree of preference for receiving oral error correction. This finding was consistent with the results of previous studies (Alhaysony, 2016; Khorshidi \& Rassaei, 2013). Papangkorn (2015) found that students preferred to receive oral error correction because they believed that it could help them to improve their linguistic accuracy. The results also revealed that (63\%) of the teachers were aware of the students' preference for receiving oral error correction. The students' and the teachers' responses to the first statement of the questionnaire are provided in Table 1.

\section{Table 1}

Preferences for receiving oral error correction

\begin{tabular}{lcccccc}
\hline \multirow{2}{*}{ Statements } & \multicolumn{2}{c}{ Male students } & \multicolumn{2}{c}{ Female students } & \multicolumn{2}{c}{ Teachers } \\
\cline { 2 - 6 } & Agree & Disagree & Agree & Disagree & Agree & Disagree \\
\hline 1. Students prefer teachers to correct oral errors & 94 & 6 & 94 & 6 & 63 & 38 \\
\hline
\end{tabular}

\subsection{Preferences for the amount of the correction}

Statements 2 and 3 elicited the participants' responses concerning the amount of oral error correction that the students want. The vast majority of the male students (98\%) and all the female students (100\%) agreed that teachers should correct frequent errors (statement 2) that students make when speaking English. Moreover, the majority of the teachers $(63 \%)$ were aware of the students' preference. The situation was different with regard to 
Alharbi, H.

correcting infrequent errors (statement 3). Although the majority of the male students (62\%) and female students $(80 \%)$ were interested in receiving correction for infrequent oral errors, the majority of the teachers $(63 \%)$ were unaware of this interest. According to Firwana (2010), teachers believe that too much correction would complicate the learning process as it would consume a great deal of time and would require the teachers to constantly interrupt the students. It is more likely that the teachers in this study have the same beliefs. The students' and the teachers' responses regarding the amount of corrections are provided in Table 2.

Table 2

Preferences for the amount of correction

\begin{tabular}{lcccccc}
\hline \multicolumn{1}{c}{ Statements } & \multicolumn{2}{c}{ Male students } & \multicolumn{2}{c}{ Female students } & \multicolumn{2}{c}{ Teachers } \\
\cline { 2 - 7 } Students want teachers to correct: & Agree & Disagree & Agree & Disagree & Agree & Disagree \\
\hline 2. The frequent errors & 98 & 2 & 100 & & 63 & 38 \\
3. The infrequent errors & 62 & 38 & 80 & 20 & 38 & 63 \\
\hline
\end{tabular}

\subsection{Preferences for self-correction and peer correction}

Statements 4 and 5 of the questionnaire were about self-correction and peer correction. As for self-correction (statement 4), the male and female students were almost equally divided between agreement and disagreement. Accordingly, an equal percentage $(52 \%)$ of both the male and female students indicated that they did not prefer to self-correct their oral errors, whereas an equal percentage (48\%) of the male and female students preferred self-correction. Calsiyao (2015) found that students preferred to self-correct their errors because they wanted to test themselves and observe if they were improving. This reason might explain why (48\%) of the male and female students in the current study preferred self-correction. The students might also want to appear smart in front of their teachers and classmates, and they feel that self-correction aids them in achieving this goal. On the other hand, the majority of the teachers $(75 \%)$ disagreed that the students preferred self-correction, whereas $25 \%$ of them agreed.

As for peer correction (statement 5), the responses of the male and female students were similar. The majority of the male students $(62 \%)$ and female students $(58 \%)$ welcomed the idea of being corrected by their peers. This finding was consistent with the finding of Zhang and Rahimi’s (2014) study.

In the current study, the majority of the teachers $(63 \%)$ were unaware that the majority of the students preferred to be corrected by their peers. Perhaps the teachers think that students do not prefer peer correction because it might create negative feelings. To illustrate, peer correction might make the students feel humiliated, and it might encourage negative competition among classmates (Kaivanpanah et al., 2015). Moreover, teachers might feel that students do not trust each other's linguistic abilities. Debreli and Onuk (2016) ascertained that students require teachers' confirmation of the correct answer; otherwise, they would not accept the correction of their peers, as they do not always trust their peers' correction. The students' and the teachers' responses to whether students prefer self-correction and peer correction are provided in Table 3.

Table 3

Preferences for self-correction and peer correction

\begin{tabular}{lcccccc}
\hline \multicolumn{1}{c}{ Statements } & \multicolumn{2}{c}{ Male students } & \multicolumn{2}{c}{ Female students } & \multicolumn{2}{c}{ Teachers } \\
\cline { 2 - 6 } & Agree & Disagree & Agree & Disagree & Agree & Disagree \\
\hline 4. Students prefer to self-correct their errors & 48 & 52 & 48 & 52 & 25 & 75 \\
$\begin{array}{l}\text { 5. Students want their classmates to correct their } \\
\text { errors }\end{array}$ & 62 & 38 & 58 & 42 & 38 & 63 \\
\hline
\end{tabular}

\subsection{Preferences for the timing of the correction}

Statements $6-9$ asked about the preferred timing for receiving the correction. The students and teachers

94 Consortia Academia Publishing (A partner of Network of Professional Researchers and Educators) 
were given four timings and were asked to indicate their agreement or disagreement with each one of them. Statement 7 "teachers wait until students finish speaking and then correct their errors" is the timing that received the highest percentage of agreement from both male students (80\%) and female students (84\%) students. This finding was in line with previous studies (Alhaysony, 2016; Kelahsarayi, 2014; Khorshidi \& Rassaei, 2013).

Although the majority of the teachers $(75 \%)$ were aware that the students preferred them to withhold the correction until they finished speaking, the teachers expressed their highest agreement (88\%) with the timing in which teachers wait until the end of the activity and then correct students' errors (statement 8). Perhaps the teachers think that the students preferred to speak freely during the activity. However, delaying the correction until the end of the activity was not highly endorsed by the male students, as only $(32 \%)$ of them preferred this timing, whereas the majority of them $(68 \%)$ did not prefer it. In addition, the female students were equally divided with regard to delaying the correction until the end of the activity, as $50 \%$ agreed and $50 \%$ disagreed.

The majority of male students $(60 \%)$ and female students $(68 \%)$ did not prefer teachers to interrupt them to offer the correction (statement 6). This finding differed from that of Calsiyao (2015), as she found that students did not mind being corrected while they were speaking. The majority of the teachers in the current study $(63 \%)$ were aware that the students did not want them to interrupt their speech to correct their errors. According to Ozmen and Aydin (2015), teachers believe that interrupting students to correct their errors is not beneficial but an impediment. Therefore, it could be that the teachers in the current study also believe this. Furthermore, $80 \%$ of the male students and $64 \%$ of the female students did not prefer teachers to delay the correction until the end of the lecture (statement 9). The majority of the teachers (63\%) were aware of this choice. According to Quinn (2014), the most common reason students gave for not preferring the delayed correction was that they might not remember their errors if the correction was delayed.

In general, the most preferred timing of error correction by both male and female students was when they finish speaking. The students' high preference for the timing in which teachers correct them after they finish speaking might indicate that the students need their teachers' assistance during the activity to formulate correct utterances. However, they do not want this assistance to interrupt them because this might confuse them or embarrass them. In contrast, the male students' least preferred timing of error correction was at the end of the lecture, whereas the female students' least preferred timing was interrupting them to correct their errors. The teachers exhibited a good level of awareness of the students' choices. The students' and the teachers' responses to the statements related to the timing of the correction are provided in Table 4.

\section{Table 4}

Preferences for the timing of the correction

\begin{tabular}{|c|c|c|c|c|c|c|}
\hline \multirow{2}{*}{$\begin{array}{l}\text { Statements } \\
\text { Students want teachers to: }\end{array}$} & \multicolumn{2}{|c|}{ Male students } & \multicolumn{2}{|c|}{ Female Students } & \multicolumn{2}{|c|}{ Teachers } \\
\hline & Agree & Disagree & Agree & Disagree & Agree & Disagree \\
\hline 6. Interrupt them in order to supply the correction. & 40 & 60 & 32 & 68 & 38 & 63 \\
\hline $\begin{array}{l}\text { 7. Wait until they finish speaking and then correct } \\
\text { their errors. }\end{array}$ & 80 & 20 & 84 & 16 & 75 & 25 \\
\hline $\begin{array}{l}\text { 8. Wait until the end of the activity and then } \\
\text { correct their errors. }\end{array}$ & 32 & 68 & 50 & 50 & 88 & 13 \\
\hline $\begin{array}{l}\text { 9. Wait until the end of the lecture and then } \\
\text { correct their errors. }\end{array}$ & 20 & 80 & 36 & 64 & 38 & 63 \\
\hline
\end{tabular}

\subsection{The degree of privacy students prefer when receiving the correction}

The aim of statements $10-13$ of the questionnaire was to determine the extent of privacy that male and female students preferred when they were being corrected. A high number of the male students (86\%) agreed to be corrected in the presence of their classmates (statement 10 ), whereas only (30\%) of them preferred to be corrected in private sessions without the presence of their classmates (statement 11). Additionally, $68 \%$ of the female students also agreed to be corrected in the presence of their classmates, whereas less than half of them 
Alharbi, $\mathrm{H}$.

(42\%) preferred teachers to correct their errors in private sessions. These findings were similar to Smith's (2010) findings. However, they contradicted the results of Pirhonen (2016), who found that students did not wish to receive oral error correction in the presence of their classmates. Pirhonen attributed students' preference for receiving the correction in private sessions to the threatening nature of oral error correction, as students do not know what teachers are going to say in front of the whole class. The majority of the teachers in the current study $(75 \%)$ thought that the students preferred to be corrected in private sessions, whereas only $(25 \%)$ of them were aware that the students preferred to receive the correction in the presence of their classmates.

Although most students seemed not to have problems with being corrected in front of their classmates, the majority of male students $(78 \%)$ and female students $(90 \%)$ preferred teachers to correct errors without identifying the student who has made the error (statement 12). In contrast, $34 \%$ of the male students and only $(10 \%)$ of the female students wanted teachers to identify the student who made the error and then provide the correction (statement 13). According to Firwana (2010), students believed that correcting errors without specifying the maker would not embarrass anybody. Furthermore, all the teachers $(100 \%)$ in this study were aware that the students preferred them to correct errors without identifying the one who has made the error. The findings indicated that the teachers were not aware that the students preferred to be corrected in the presence of their classmates, but they were aware that the students would prefer them to correct oral errors without specifying a particular student. Additionally, male and female students had similar preferences regarding the degree of privacy when receiving the correction. The students' and the teachers' responses to the statements pertaining to the extent of privacy that the students prefer to have when receiving the correction are presented Table 5 .

Table 5

The degree of privacy the students prefer when receiving the correction

\begin{tabular}{lcccccc}
\hline \multirow{2}{*}{ Statements } & \multicolumn{2}{c}{ Male students } & Female students & \multicolumn{2}{c}{ Teachers } \\
\cline { 2 - 7 } Students want teachers to correct errors: & Agree & Disagree & Agree & Disagree & Agree & Disagree \\
\hline 10. In the presence of their classmates & 86 & 14 & 68 & 32 & 25 & 75 \\
11. In private sessions & 30 & 70 & 42 & 58 & 75 & 25 \\
12. Without identifying the error maker & 78 & 22 & 90 & 10 & 100 & \\
13. With identifying the error maker & 34 & 66 & 10 & 90 & 25 & 75 \\
\hline
\end{tabular}

The significance of Pearson Chi-Square is $0.194>$ P. value 0.05. Accordingly, there are no differences between the male and female Saudi EFL students in terms of their preferences for correction of classroom oral errors in section one of the questionnaires.

\subsection{Types of errors students prefer to be corrected}

The second section of the questionnaire consisted of five statements related to the types of errors that students would prefer to be corrected. The findings demonstrated that grammatical errors (statement 14) gained the highest percentage of agreement from male and female students. An equal percentage (98\%) of both male and female students agreed with the correction of grammatical errors. Furthermore, $75 \%$ of the teachers were aware of this preference. Sofi (2015) found that teaching English in Saudi Arabia focuses on teaching grammar. According to Schulz (1996), students who experienced classrooms that are full of grammar instruction are usually interested in learning grammar. This might explain why the Saudi students in this study showed a high preference for grammatical error correction.

The grammatical errors were followed by vocabulary errors (statement 16). An equal percentage (94\%) of both male and female students preferred teachers to correct vocabulary errors. The students were expected to express a high preference for the correction of this type of error because one of the most common reasons that the students that I met provided for their reluctance to speak in the classroom was that they did not have enough vocabulary to express their ideas. Interestingly, all teachers (100\%) were aware that the students preferred the correction of vocabulary errors. The findings that the students in this study exhibited a high preference for the

96 Consortia Academia Publishing (A partner of Network of Professional Researchers and Educators) 
Saudi EFL students' preferences for correction of classroom oral errors: Are teachers aware?

correction of grammatical errors and vocabulary errors were similar to the results of previous studies (Kazemi et al., 2013; Kim, 2015).

Phonological errors (statement 15) drew the third-highest percentage of agreement from the male and female students. The majority of both male students (86\%) and female students $(90 \%)$ preferred teachers to correct their phonological errors. The majority of the teachers in the current study (88\%) were aware of this preference. The finding that Saudi EFL students highly agreed with phonological error correction concurs with the finding of Calsiyao (2015), who revealed that Filipino students had a high degree of interest in the correction of phonological errors. Calsiyao attributed this result to the vast difference between the Filipino and English phonology. According to Calsiyao, this difference makes it difficult for Filipino students to acquire correct English pronunciation. Similar reason might also account for Saudi students' high preference for the correction of phonological errors. Saudi EFL students face a number of pronunciation problems (Hago \& Khan, 2015). To illustrate, Hameed and Aslam (2015) established that Saudi EFL students do not know how to distinguish between similar sounds in English such as $/ \mathrm{p} /$ and $/ \mathrm{b} /$.

Furthermore, discourse organization errors (statement 18) and errors of inappropriate expressions (statement 17) received the lowest percentages of agreement from both male and female students. As such, an equal percentage $(84 \%)$ of both male and female students preferred teachers to correct discourse organization errors. The teachers' responses were equally divided with regard to these types of errors. Accordingly, $50 \%$ of the teachers were aware that the students preferred teachers to correct discourse organization errors, whereas the other $(50 \%)$ were unaware. In addition, $80 \%$ of the male students and $74 \%$ of the female students preferred teachers to correct errors of inappropriate expressions. The majority of the teachers $(75 \%)$ were aware that the students preferred to receive correction for this type of errors.

The significance of Pearson Chi-Square was $.890>p$ value .05 . Therefore, there were no differences between male and female Saudi EFL students with regard to the types of errors that they prefer to be corrected. Only a few students disagreed with receiving correction for the types of errors investigated. Accordingly, it can be argued that students considered all these types of errors to be important and worthy of attention. The teachers' responses in the second part of the questionnaire revealed that they were aware of most of the students' preferences regarding the scope of the correction. The students' and the teachers' responses to the statements concerning the types of errors that the students prefer to be corrected are summarized in Table 6.

\section{Table 6}

Types of errors students prefer to be corrected

\begin{tabular}{lcccccc}
\hline \multirow{2}{*}{ Types of Errors } & \multicolumn{2}{c}{ Male students } & \multicolumn{2}{c}{ Female Students } & \multicolumn{2}{c}{ Teachers } \\
\cline { 2 - 7 } Students prefer teachers to correct: & Agree & Disagree & Agree & Disagree & Agree & Disagree \\
\hline 14. Grammatical errors. & 98 & 2 & 98 & 2 & 75 & 25 \\
15. Phonological errors. & 86 & 14 & 90 & 10 & 88 & 13 \\
16. Vocabulary errors. & 94 & 6 & 94 & 6 & 100 & 75 \\
17. Errors of inappropriate expressions. & 80 & 20 & 74 & 26 & 25 \\
18. Discourse organization errors. & 84 & 16 & 84 & 16 & 50 & 50 \\
\hline
\end{tabular}

\subsection{Preferences for oral error correction technique}

The third section of the questionnaire included ten techniques that teachers use to correct students' oral errors. The students and teachers were asked to indicate their agreement or disagreement with each one of these techniques. The students' responses revealed that the vast majority of both male students (96\%) and female students (98\%) preferred the technique in which teachers point out the error and provide the correct response (statement 19). This finding was consistent with the finding of and Rahimi (2014), who found that Iranian EFL students preferred the same technique. This technique is called explicit correction (Lyster \& Ranta, 1997). The majority of the teachers in this study (75\%) were aware of the students' preference for explicit correction. 
Alharbi, $\mathrm{H}$.

As for the technique in which the teacher repeats what the students have said by replacing the error with the correct response (statement 20), a large number of the male students (90\%) and female students (84\%) preferred teachers to use this technique to correct their oral errors. Lyster and Ranta (1997) called this technique recast. All the teachers $(100 \%)$ were aware that the students preferred the recast technique. Yoshida (2008) demonstrated that recast was the most frequently used technique by teachers as they believe that recast is less time-consuming and less intimidating than other techniques. Moreover, over half of the male students (54\%) and the female students $(64 \%)$ did not prefer the technique in which the teachers pretend that they did not understand what students have said and then ask them to repeat their utterances (statement 21). Perhaps the students do not feel comfortable to be corrected by using this technique because it is difficult to determine whether their teachers did not understand their utterances or just wanted them to notice their errors. Lyster and Ranta (1997) identified this technique as a clarification request. The majority of the teachers $(75 \%)$ were unaware that the students did not prefer the clarification request technique.

The vast majority of male students (96\%) and female students (98\%) preferred the technique in which the teachers explain why the response is incorrect (statement 22). This technique is a form of what Lyster and Ranta (1997) called a metalinguistic correction. According to Lyster and Ranta, metalinguistic feedback attempts to elicit the correct answer from students by asking questions or providing information about it. All the teachers in this study (100\%) were aware that the students preferred them to use this form of metalinguistic correction. Another form of metalinguistic feedback that was investigated in this study is the technique in which teachers give students a hint that might enable them to notice the error and self-correct (statement 23). This technique was found to be welcomed by the majority of male students $(82 \%)$ and female students $(86 \%)$. The majority of the teachers in the current study (75\%) were aware that this form of metalinguistic correction is a preferred technique among the students. The results in this study about metalinguistic correction were in agreement with those reported by Al-Faki and Siddiek (2013), who revealed that Omani EFL students preferred metalinguistic correction.

A large number of male students (82\%) and female students (80\%) preferred the technique in which teachers repeat what students have said up to the error and then stop and wait for students to self-correct (statement 24). This technique is one example of the elicitation technique (Lyster \& Ranta, 1997). The students' preference for this form of elicitation was in accordance with Calsiyao's (2015) finding, but in contrast to that of Abedi et al. (2015). All of the teachers (100\%) in this study were aware that the students preferred this technique. The technique in which teachers repeat what students have said and pronounce the erroneous part with higher intonation (statement 25) is called repetition (Lyster \& Ranta, 1997). Both male students (68\%) and female students $(70 \%)$ in the current study indicated that they preferred this technique. A similar result was obtained by Alamri and Fawzi (2016). Additionally, more than half of the teachers $(63 \%)$ were aware that the students preferred them to use the repetition technique to correct their oral errors.

In addition, more than half of the male students $(62 \%)$ and female students (72\%) preferred the technique in which teachers indicate that an error occurred by nonverbal behavior (statement 26). The majority of the teachers (75\%) were not aware that using nonverbal behavior to indicate the existence of an error was a preferable technique among the students. As expected, a substantial number of male students (90\%) and female students (98\%) did not prefer the technique by which teachers ignore students' errors (statement 27). Interestingly, all the teachers $(100 \%)$ were aware that the students did not want them to ignore their oral errors.

The significance of Pearson Chi-Square was $.940>p$ value .05 . This means that there were no differences between male and female Saudi EFL students in terms of their preferences for oral errors correction techniques. Overall, most of the investigated techniques received positive responses from both male and female students. The results revealed that the technique that drew the highest percentage of agreement from male and female students was the one in which teachers explain why the response is incorrect. Moreover, the technique that drew the highest percentage of disagreement from male and female students in this study was ignorance. This finding confirmed the results of previous studies (Abedi et al., 2015; Al-Faki \& Siddiek, 2013; Kazemi et al., 2013).

98 Consortia Academia Publishing (A partner of Network of Professional Researchers and Educators) 
The teachers in the current study displayed a high degree of awareness of the students' preferences for the correction techniques. However, they were not aware that the students did not prefer the use of the clarification request technique. Furthermore, they were unaware of the students' preference for nonverbal correction. The students' and teachers' responses to oral error correction techniques are presented in Table 7.

Table 7

Preferences for oral error correction techniques

\begin{tabular}{|c|c|c|c|c|c|c|}
\hline \multirow{2}{*}{ Techniques } & \multicolumn{2}{|c|}{ Male students } & \multicolumn{2}{|c|}{ Female students } & \multicolumn{2}{|c|}{ Teachers } \\
\hline & Agree & Disagree & Agree & Disagree & Agree & Disagree \\
\hline $\begin{array}{l}\text { 19. Teachers point out the error and provide the } \\
\text { correct response, such as "Go is wrong. You } \\
\text { should say went." }\end{array}$ & 94 & 6 & 98 & 2 & 75 & 25 \\
\hline $\begin{array}{l}20 . \text { Teachers repeat what students have said with } \\
\text { replacing the error with the correct response such } \\
\text { as "I went to the park." }\end{array}$ & 90 & 10 & 84 & 16 & 100 & \\
\hline $\begin{array}{l}\text { 21. Teachers pretend that they did not understand } \\
\text { what students have said and then ask students to } \\
\text { repeat their utterances, such as "Please say that } \\
\text { again." }\end{array}$ & 46 & 54 & 36 & 64 & 75 & 25 \\
\hline $\begin{array}{l}\text { 22. Teachers explain why the response is } \\
\text { incorrect, such as "Go is the present tense. You } \\
\text { need the past tense here." }\end{array}$ & 96 & 4 & 98 & 2 & 100 & \\
\hline $\begin{array}{l}\text { 23. Teachers give students a hint that might } \\
\text { enable them to notice the error and self-correct, } \\
\text { such as "Where did you say you went yesterday?" }\end{array}$ & 82 & 18 & 86 & 14 & 75 & 25 \\
\hline $\begin{array}{l}\text { 24. Teachers repeat what students have said up to } \\
\text { the error and then stop and wait for students to } \\
\text { self-correct, such as "I....." }\end{array}$ & 82 & 18 & 80 & 20 & 100 & \\
\hline $\begin{array}{l}25 . \text { Teachers repeat what students have said with } \\
\text { pronouncing the erroneous part of the utterance } \\
\text { with higher intonation. }\end{array}$ & 68 & 32 & 70 & 30 & 63 & 38 \\
\hline $\begin{array}{l}\text { 26. Teachers indicate that an error occurred by } \\
\text { nonverbal behavior, such as gestures and facial } \\
\text { expressions. }\end{array}$ & 62 & 38 & 72 & 28 & 25 & 75 \\
\hline 27. Teachers ignore students' errors. & 10 & 90 & 2 & 98 & & 100 \\
\hline
\end{tabular}

\subsection{Implications}

This study conveys that when we activate the students' role in the educational system and open the doors for them to participate in determining how they learn; this can improve their learning experience. The students would feel a sense of belonging to the learning environment if they can take part in forming its features. They would also feel that they are in a place that appreciates their beliefs and preferences, and this feeling can motivate them to learn. Even under circumstances in which it is not possible to follow the students' preferences, the teachers need to explain the reasons for the students and help them to consider the issues that they are unaware of. The convergence between the views of the teachers and the students could lead to smoother interaction between the two groups in class.

The students' high preference for oral error correction proved that error correction does not cause frustration for the students. Perhaps most of, if not all, the cases of students who did not succeed in English language learning or even hated English language classes were as a result of the methods that the teachers used to make correction and not because of the correction itself, as we thought. As highlighted in this study, the students were not against corrections but they were against interrupting them to provide the correction. Therefore, every educational institution should endeavor to explore the students' preferences for oral error correction and seeking to match these preferences. 


\section{Conclusions}

Saudi EFL male and female university students had similar preferences for oral error correction. This finding confirmed the result of Khorshidi and Rassaei's study (2013), in which they established that the male and female Iranian EFL students were similar in a number of aspects of their preferences for oral error correction. The findings of this study were also in line with the results of Papangkorn's study (2015), who revealed that male and female Thai EFL students shared similar preferences for oral error correction. On the other hand, this study's findings contrasted with the results of Alhaysony (2016), who reported that the perception of the Saudi male and female EFL students differed significantly with regard to oral error correction. Alhaysony (2016) stated that the female Saudi EFL students in her study had a higher desire for receiving oral error correction when she compared their preferences to the male students' preferences. However, in this study both the male and female students displayed a high preference for receiving the correction.

The contradiction between the two studies' results might result from the fact that the male and female students in Alhaysony's study (2016) were preparatory year students at Hail University. They belonged to three different tracks: the medical track, the science track and the humanities track. Therefore, the student's fields and goals were different, and this could increase the gap between the preferences of the male and female students. Whereas all the male and female students in this study enrolled in the same English program, and they sought to achieve the same goal that is passing the course to join the department of English Language and Translation at Qassim University. Accordingly, the male and female students' preferences were highly similar. Furthermore, male and female students' responses to the statement "I prefer to self-correct errors that I make when speaking English" were almost equally divided between agreeing and disagreeing. However, when the students were presented with a number of techniques that teachers use to correct students' oral errors, male and female students exhibited clear preferences for the techniques that encourage them to self-correct their errors such as metalinguistic correction.

It was very surprising to find that although the students preferred teachers to correct errors without identifying the error maker, they did not prefer to receive the correction in private sessions. One possible explanation for this is that the private sessions might make the students feel uncomfortable, particularly when they know that teachers are going to talk about their errors. The teachers in this study were aware of most of the students' preferences. Furthermore, they showed consensus in their responses with regard to six statements in the questionnaire, and their consensus matched the students' preferences. These statements were: correcting errors without identifying the error maker, correcting vocabulary errors, using recast, elicitation and metalinguistic techniques and ignoring students' errors. Further research is recommended to ascertain whether the teachers' gender affects their awareness of students' preferences as this study did not investigate this variable. Further research is also recommended to investigate other variables that might have an effect on the Saudi EFL students' preferences for oral error correction such as the proficiency level in English and anxiety levels. It would also be useful to explore the reasons for the students' preferences to gain a better understanding of their preferences.

Acknowledgment: I express my deepest gratitude to Dr. Arafat Hamouda for his insightful guidance and encouragement throughout this project. Additionally, I am specifically indebted to Dr. Ahmad Alhojailan, who helped me to deliver the questionnaire to the male participants. I would also like to express my gratitude to the members of the jury who aided in validating the research instrument: Dr. Abdoulaye Mbaye, Dr. Ahmad Alhojailan, Dr. Mohammad Alseweed, and Dr. Zaidan Jassem. Their comments and suggestions have been constructive. Finally, my sincerest gratitude goes to the participants who gave their valuable time to make this study come to reality.

\section{References}

Abedi, D., Mahdavi, Z. A., \& Hassaskhah, J. (2015). Iranian EFL learners' preferred oral corrective feedback: 
Saudi EFL students' preferences for correction of classroom oral errors: Are teachers aware?

High anxious learners vs. low anxious learners. International Journal of Research Studies in Language Learning, 5(2), 1-12. https://doi.org/10.5861/ijrsll.2015.1121

Alamri, B., \& Fawzi, H. (2016). Students' preferences and attitude toward oral error correction techniques at Yanbu University College, Saudi Arabia. English Language Teaching, 9(11). https://doi.org/10.5539/elt.v9n11p59

Al-Faki, I., \& Siddiek, A. G. (2013). Techniques used by teachers in correcting students' oral errors in an Omani boys school. Theory and Practice in Language Studies, 3(10), 1770-1783.

Alhaysony, M. (2016). Saudi EFL preparatory year students' perception about corrective feedback in oral communication. English Language Teaching, 9(12), 47-61. https://doi.org/10.5539/elt.v9n12p47

Almuhimedi, R. A., \& Alshumaimeri, Y. A. (2015). Effective error correction in grammar classes: A students' perspective. American International Journal of Contemporary Research, 5(6), 127-138.

Alrabai, F. (2014). A model of foreign language anxiety in the Saudi EFL context. English Language Teaching, 7(7), 82-101. https://doi.org/10.5539/elt.v7n7p82

Alrashidi, O., \& Phan, H. (2015). Education context and English teaching and learning in the Kingdom of Saudi Arabia: An overview. English Language Teaching, 8(5), 33-44. https://doi.org/10.5539/elt.v8n5p33

Al-Saraj, T. M. (2014). Foreign language anxiety in female Arabs learning English: Case studies. Innovation in Language Learning and Teaching, 8(3), 257-278. https://doi.org/10.1080/17501229.2013.837911

Azar, A. S., \& Molavi, S. (2013). Iranian EFL learners' attitudes toward correction of oral errors. The European Journal of Social and Behavioral Sciences, 4(52), 801-818.

Baz, E. H., Balçıkanlı, C., \& Cephe, P. T. (2016). Perception of English instructors and learners about corrective feedback. European Journals of Education Studies, 1(1), 54-68.

Brown, J. D. (2011). Quantitative research in second language studies. In E. Hinkel (Ed.), Handbook of research in second language teaching and learning (pp. 190-207). Routledge.

Calsiyao, I. (2015). Corrective feedback in classroom oral errors among Kalinga-Apayao State College students. International Journal of Social Science and Humanities Research, 3 (1), 394-400.

Cohen, L., Manion, L., \& Morrison., K. (2000). Research methods in education. Routledge.

Cronbach, L. J., \& Shavelson, R. J. (2004). My current thoughts on Coefficient alpha and successor procedures. Educational and Psychological Measurement, 64(3), 391-418. https://doi.org/10.1177\%2F0013164404266386

Debreli, E., \& Onuk, N. (2016). The Influence of educational program on teachers' error correction preferences in the speaking skill: Insights from English as a foreign language context. International Education Studies, 9(6), 76-85. https://doi.org/10.5539/ies.v9n6p76

Dörnyei, Z. (2007). Research methods in applied linguistics: Quantitative, qualitative, and mixed methodologies. Oxford University Press.

Elyas, T., \& Al Grigri, W. H. (2014). Obstacles to teaching English in Saudi Arabia public schools: Teachers' and supervisors' perceptions. International Journal of English Language Teaching, 2(3), 74-89.

Farahani, A. A., \& Salajegheh, S. (2015). Iranian teachers' and students' preferences for correction of classroom oral errors: Opinions and responses. Argentinean Journal of Applied Linguistics, 3(1), 14-25.

Fidan, D. (2015). Learners' preferences of oral corrective feedback: An example of Turkish as a foreign language learners. Educational Research and Reviews, 10(9), 1311-1317. https://doi.org/10.5897/ERR2015.2162

Firwana, S. S. (2010). Impact of Palestinian EFL teachers' attitudes toward oral errors on their students' attitudes and choice of error treatment strategies [Unpublished doctoral dissertation]. Boston College.

Fukuda, Y. (2004). Error treatment in oral communication classes in Japanese high schools [Unpublished master's thesis]. San Francisco State University.

Genç, Z. (2014). Correcting spoken errors in English language teaching: Preferences of Turkish EFL learners at different proficiency levels. Education and Science, 39(174), 259-271.

Hago, O. E., \& Khan, W. H. (2015). The pronunciation problems faced by Saudi EFL learners at secondary schools. Education and Linguistics Research, 1(2), 85-99. https://doi.org/10.5296/elr.v1i2.7783

Hameed, P., \& Aslam, M. (2015). Pronunciation as a stumbling block for the Saudi English learners: An analysis of the problems and some remedies. Theory and Practice in Language Studies, 5(8), 1578-1585. 
Alharbi, H.

https://doi.org/10.17507/tpls.0508.06

Hamouda, A. (2013). An exploration of causes of Saudi students' reluctance to participate in the English language classroom. International Journal of English Language Education, 1(1), 17-34. https://doi.org/10.5296/ijele.v1i1.2652

Kaivanpanah, S., Alavi, S. M., \& Sepehrinia, S. (2015) Preferences for interactional feedback: Differences between learners and teachers. The Language Learning Journal, 43(1), 74-93 https://doi.org/10.1080/09571736.2012.705571

Jackson, S. L. (2012). Research methods and statistics: A critical thinking approach. Cengage learning.

Katayama, A. (2007). Japanese EFL students' preferences toward correction of classroom oral errors. Asian EFL Journal, 9(4), 289-305.

Kazemi, R., Araghi, S. M., \& Davatgari, H. (2013). Iranian EFL learners' preferences toward classroom oral error correction: With a main focus on their proficiency level. Theory and Practice in Language Studies, 3(11), 1996-2003.

Kelahsarayi, T. R. (2014). Extrovert and introvert learners' attitudes and preferences for error correction in speaking. Asian Journal of Research in Social Sciences and Humanities, 4(9,) pp. 268-286. https://doi.org/10.5958/2249-7315.2014.00988.5

Khorshidi, E., \& Rassaei, E. (2013). The effects of learners' gender on their preferences for corrective feedback. Journal of Studies in Learning and Teaching English, 1(4), 71-83.

Kim, K. (2015). Similarities and differences between teachers' and students' views on corrective feedback-Korean context. The Bridge: Journal of Educational Research-Informed Practice, 2(3), 42-70.

Lyster, R. (1998). Recasts, repetition, and ambiguity in L2 classroom discourse. Studies in Second Language Acquisition, 20(1), 51-81. https://doi.org/10.1017/S027226319800103X

Ozmen, K. S., \& Aydın, H. Ü. (2015). Examining student teachers' beliefs about oral corrective feedback: Insights from a teacher education program in Turkey. Australian Journal of Teacher Education, 40(12), 141-164. https://doi.org/10.14221/ajte.2015v40n12.10

Papangkorn, P. (2015). SSRUIC students' attitude and preference toward error corrections. Procedia - Social and Behavioral Sciences, 197, 1841-1846. https://doi.org/10.1016/j.sbspro.2015.07.244

Pirhonen, N. (2016). Students' perceptions about the use of oral feedback in EFL classrooms [Unpublished master's thesis]. University of Jyvaskyla. https://api.semanticscholar.org/CorpusID:148147470

Qasaimeh, M., \& Gasaymeh, A. M. (2016). Assessment of English language preferences of the methods of teaching English in a private Jordanian university. Journal of Studies in Education, 6(1) 112-128. https://doi.org/10.5296/jse.v6i1.8779

Quinn, P. (2014). Delayed versus immediate corrective feedback on orally produced passive errors in English. [Unpublished doctoral dissertation]. University of Toronto.

Schulz, R. A. (2001). Cultural differences in student and teacher perceptions concerning the role of grammar instruction and corrective feedback: USA-Colombia. The Modern Language Journal, 85(2), 244 - 258. https://doi.org/10.1111/0026-7902.00107

Smith, H. (2010). Correct me if I'm wrong: Investigating the preferences in error correction among adult English language learners. [Unpublished master's thesis]. University of Central Florida.

Sofi, L. (2015). Teaching English in Saudi Arabia through the use of multimedia [Master's thesis]. The University of San Francisco.

Tavakol, M., \& Dennick, R. (2011). Making sense of Cronbach's alpha. International Journal of Medical Education, 2, 53-55.https://doi.org/10.5116/ijme.4dfb.8dfd

Yoshida, R. (2008). Teachers' choice and learners' preference of corrective feedback types. Language Awareness, 17(1), 78-93. https://doi.org/10.2167/la429.0

Yousefi, V. (2016). Corrective feedback preferences among Iranian EFL students. International Journal of Research Studies in Language Learning, 5(2), 37-45. https://doi.org/10.5861/ijrsll.2015.1101

Zhang, L. J., \& Rahimi, M. (2014). EFL learners' anxiety level and their beliefs about corrective feedback in oral communication classes. System, 24, 429-439. https://doi.org/10.1016/j.system.2014.01.012

102 Consortia Academia Publishing (A partner of Network of Professional Researchers and Educators) 